\title{
THE RIGHT TO STRIKE IN THE EDUCATION SECTOR IN LIGHT OF CONSTITUTIONAL PROVISIONS AND INTERNATIONAL LEGAL OBLIGATIONS
}

\begin{abstract}
The main area of interest of this paper focuses on the right to strike in public education sector. All the possibilities of limiting the right to strike in this public sector needs to be verified in the context of constitutional provisions and international legal obligations binding the legislator. The possibility of "including" teachers in the Civil Service Corps is being considered in this paper. Under the current state of law, there are no grounds to restrict or prohibit the right to strike in the education sector. The potential subordination of teachers to the rigours binding the Civil Service Corps would require far-reaching adjustments within this institution, stemming from the constitutional provisions that would necessitate these changes.
\end{abstract}

Słowa kluczowe: prawo do strajku nauczycieli, służba cywilna

Keywords: the right to strike in public education sector, civil service corps

ASJC: 3308, JEL: K31

\section{Introduction}

To date, the legality of strike actions taken by teaching staff has not been questioned in the jurisprudence and the subject literature. Recent strikes that have taken place in the education sector and the ensuing public debate necessitate clarification of the subject. First of all, the possibility of limiting the right to strike in this public sector needs to be verified in the context of constitutional provisions and international legal obligations binding the legislator. One of the issues to be considered is the possibility of "including" teachers in the Civil Service Corps. 


\section{Person-related and field-related limitation of the right to strike}

Pursuant to Art. 59(3) of the Constitution of the Republic of Poland (Dz.U. 1997, No. 78, item 483 as amended, hereinafter referred to as: Constitution) trade unions are entitled to organise strikes and other forms of protest. However, this right is vested within the limits of this legal act and may be restricted or prohibited for reasons of public interest. The Constitution provides that strike prohibition or restriction on the right to strike may pertain to a specific group of employees (person-related limitation) or specific fields (field-related limitation).

Currently, this matter is subject to the provisions set out in Art. 19 of the Act of 23 May 1991 on solving collective labour disputes (Dz.U. 2019, item 174 consolidated text, as amended, hereinafter referred to as: a.s.c.l.d.). Field-related limitations of the right to strike are provided for in Art. 19(1) of the a.s.c.l.d. Pursuant to this provision, any work stoppage because of the strike that affects positions, equipment and installations, where the interruption of work constitutes a hazard to human lives or health or to the security of the State, shall be prohibited. Irrespective of that provision, the possibility of strikes has been prohibited with respect to military forces listed in Art. 19(2) of the a.s.c.l.d. ${ }^{1}$ On the other hand, person-related limitation of the right to strike has been expressed in item 3 of this article, which states that persons employed in State authorities, government and self-government administration, courts and public prosecutor's offices shall not have the right to strike.

With regard to person-related limitations of the right to strike, there have been accusations in the subject literature that Art. 19(2) of the a.s.c.l.d. does not comply with the provisions of Convention No. 87 on Freedom of Association and Protection of the Right to Organize (Dz.U. 1958, No. 29, item 125). According to Andrzej M. Świątkowski, in light of this Convention and its interpretation made by the Freedom of Association Committee of the International Labour Organisation (ILO) "prohibiting the use of one's right to strike cannot be equated with depriving given categories of public servants of the right to strike" (Świątkowski 2009). Thus, he draws a conclusion that Art. 19(3) of the a.s.c.l.d. is grossly incompatible with this Convention. In light of this controversy, it needs to be noted that an absolute strike prohibition is also stipulated pursuant to Art. 78(3) of the Act of 21 November 2008 on Civil Service (Dz.U. 2018, item 1559 consolidated text, as amended, hereinafter referred to as: a.c.s.).

1 According to Tomanek (2016): "Due to its special nature, Art. 19(2) of the a.s.c.l.d. cannot be subject to extensive interpretation. Thus, it seems justified to conclude that workers employed in working places operating outside the organisational structure of the above-mentioned military forces, but providing them with auxiliary services or other services, have the right to strike in line with general provisions." 


\section{Constitutional framework for the objectives of the Civil Service Corps}

The Civil Service Corps members are directly bound by restrictions, or rather a framework which shapes the way they exercise particular freedoms and human and citizen rights. This framework stems from the principle of a democratic state governed by the rule of law set out in the above-mentioned Art. 2 of the Constitution. Undoubtedly, this very principle implies the guarantee of continuity and predictability of State authorities' actions, which are to be ensured by the neutrality of the Civil Service Corps members. The Constitutional Court has emphasised on numerous occasions that the legislator in a democratic state of law is obliged to guarantee reliability of actions undertaken by public institutions. One of such guarantees is, e.g., political neutrality (see judgment of the Constitutional Court of 21 October 1998, K 24/98, Legalis 44983; judgment of the Constitutional Court of 10 April 2002, K 26/00, LEX 54052). This enables the legislator in a democratic society to create gradation between values protected in such a way that allows for favouring public interest whenever necessary. However, what is of key importance in the context of the subject discussed is Art. 153(1) of the Constitution. The article specifies that the objective for civil servants, as a special category of officials operating in the organs of government administration, is to ensure "a professional, reliable, impartial and politically neutral execution of the State's obligations." This constitutional law is to be observed under Art. 78(1) of the a.c.s., whereby the Civil Service Corps members cannot be guided in executing their duties neither by their particular nor any group interests. The subsequent items of the article provide further details of this ban, which directly interfere with constitutional freedoms and rights, such as prohibition of: public manifestation of political beliefs, membership in political parties, or the discussed herein participation in strikes or actions of protest, which would interfere with regular functioning of an Office (Art. 78(3) of the a.c.s.).

It is assumed in the subject literature that an effect in the form of interference with regular functioning of an Office pertains to an action of protest other than strike. With regard to a strike, this ban is absolute (Rotkiewicz 2018). This might be explained by the fact that a strike action, which as a rule involves work stoppage, always interferes with regular functioning of an Office. Thus, the very semantic structure of the provision excludes the possibility of relativisation of this ban in relation to the potential effects of participation in a strike.

The Constitution does not explicitly define the tasks to be performed by the Civil Service Corps. Naturally, this does not mean that the ordinary legislator has a free choice in this respect. In this context, Art. 2 of the Constitution remains the constitutional norm. On one hand, when establishing legal norms, the legislator is obliged by the principle of a democratic state of law to guarantee the continuity and predictability of the function of State authorities, including the assurance of providing constitutionally guaranteed public services. In this context, it needs to be emphasised that Art. 2 of the Constitution does not refer to a democratic state of law as such but is associated with 
the goal of implementing the principles of social justice. A democratic state ruled by law cannot be understood in the spirit of laissez faire, where its only role is to be a legal guarantor of civil liberties. Pursuant to Art. 2 of the Constitution, one can expect that the State will guarantee a certain standard of social justice in the relations between individuals. This, in turn, provides broader grounds for the legislator's interference in the exercise of constitutional rights and freedoms, including the right to strike.

On the other hand, the nature of limitations guaranteeing independence and impartiality of civil servants performing their duties necessitates that the decision of the legislator about assigning certain State's obligations to civil servants be analysed also in the context of Art. 31(3) of the Constitution. Pursuant to this provision, any limitation upon the exercise of constitutional rights and freedoms may be imposed only by statute, and only when necessary in a democratic state for the protection of its security or public order, or to protect the natural environment, health or public morals, or the freedoms and rights of other persons. Furthermore, such limitations shall not violate the essence of freedoms and rights.

The Constitution does not define a list of obligations assigned to civil servants. However, an analysis of Art. 153(1) together with Art. 32(3) thereof points to a conclusion that the legislator must not abuse this institution, extending its rigours onto other occupational groups, unless necessary in a democratic state. Such actions could collide with the constitutionally guaranteed freedom to practice a profession.

The above-mentioned considerations seem important for two reasons. First, as rightly noted by J. Stelina, there is currently no model of civil service that would be commonly accepted in democratic states (Stelina 2013, p. 159). Thus, it seems that in the Polish setting the civil service model will evolve in terms of both ordinary and constitutional legislation. Therefore, it seems necessary to confront this model with other, more established constitutional values and principles.

Second, even today the assessment of the scope of limitations in exercising constitutional rights and freedoms, related to being a member of the Civil Service Corpsalso due to the laconic character of Art. 153 of the Constitution-requires a broader constitutional context. It seems that this provision does not directly allow to derive either the scope of tasks assigned to the civil service or the discussed prohibition of civil servants' right to strike.

Assessing the correctness of the definition of the Civil Service Corps, the Constitutional Court examined the subject not so much in the context of the protection of constitutional rights and freedoms as civil service statutory position in the State's structure. The Court based its considerations mainly on the principle expressed in Art. 153(1) of the Constitution, which states that a corps of civil servants is appointed to operate "in the organs of government administration" and, pursuant to Art. 153(2) of the Constitution, the Prime Minister shall be the superior of the corps of civil servants. Hence the thesis that "constitutional placement of the Civil Service Corps within the organs of government administration and its reporting to the Prime Minister as the superior exclude statutory extension of this corps to include those segments of the State that are not part 
of government administration." The Court emphasised that constitutional provisions regulating the scope of responsibilities and competences of authorities are subject to strict interpretation. Furthermore:

\begin{abstract}
Extension of the Civil Service Corps by the ordinary legislator to include segments other than government administration of the State would be an unacceptable modification of the constitutional system. This is because government administration differs from self-government or state administration, although all three of them can be regarded as public administration (judgment of the Constitutional Court of 28 October 1999, K 3/99, LEX 37318).
\end{abstract}

Adopting such a model of the civil service, the constitutional legislator combined the execution of State's obligations with exercising a particular scope of public authority, which is state authority, within the civil service. In this context, teachers cannot simply be "included" in the Civil Service Corps without changes of relevant constitutional provisions. Another question is whether such changes would conform to the international legal obligations Poland has to comply with. Even though examples from other European countries (e.g. Germany) seem to allow for such a possibility, a deeper analysis of this subject raises certain doubts in this respect.

\title{
4. The right to strike in the education sector based on Art. 11(1) of the Convention for the Protection of Human Rights and Fundamental Freedoms
}

The Convention for the Protection of Human Rights and Fundamental Freedoms does not directly establish the right to strike. However, it seems that the right to strike is protected pursuant to Art. 11(1) of the Convention, which guarantees the freedom of assembly and association in trade unions for the protection of one's interests.

In the decision of 15 May 2018, application No. 2451/16 (Association of Academics v. Iceland), the European Court of Human Rights proposed a list of essential elements of freedom of association in trade unions, without which that freedom would become devoid of substance. These elements include "the right to form and join a trade union; the prohibition of closed-shop agreements; the right for a trade union to seek to persuade the employer to hear what it has to say on behalf of its members, and the right to bargain collectively with an employer" (translation by LEX 2497963). At the same time, the Court stipulated that the list is not exhaustive and is subject to evolution due to changes in labour relations.

In the decision, the Court did not qualify industrial action, including strike action, as an essential element of trade union freedom. However, it found that, as a commonly accepted part of trade union activity, strike is protected by Art. 11 of the Convention. The Court ruled that a threat to the right to health care, as a constitutional right of citizens, 
forms a sufficient and acceptable ground in a democratic society to restrict the right to take strike action in the health care sector.

The subject of strike in the education sector was analysed by the European Commission of Human Rights in its decision of 5 July 1984, application No. 10365/83 (pp. 237-241). The case pertained to a German teacher, a long-standing member of a trade union, who during a union meeting called on other teachers (having the status of civil servants in the Federal Republic of Germany) to participate in a 2-hour strike action. The strike was to draw the public attention to working conditions in the education sector. The trade union in question fought for e.g. reduction of teachers' working hours. Union members, including the applicant, received a disciplinary penalty. The decision was upheld by the Federal Constitutional Court in FRG.

The European Commission of Human Rights deemed the right to strike an important element of exercising the right to associate in trade unions. However, it pointed out that this freedom can also be secured using other means, especially in the case of civil servants. In the case discussed, the Commission did not provide a direct response as to whether prohibiting the teachers from going on strike violated Art. 11(1) of the Convention. This is because participation in making the decision to call a strike was not directly associated with exercising the right to strike. Therefore, the Court decided that there had been no need to examine whether such general failure to recognise civil servants' right to strike violated Art. 11(1) of the Convention. Still, in its decision of 20 October 1997, application No. 31117/96 (Agko v. Greece), the European Commission of Human Rights, referring to the above-mentioned decision (of 3 July 1984), clearly stated that "Art. 11 (Art. 11) of the Convention does not guarantee the right of civil servants to strike" (Agko v. Greece). However, this case did not pertain to a strike action defending the collective, professional interests of teachers. Here, the Greek Council of State clearly indicated that "dismissal would not have been the appropriate penalty for a few days' absence from work, if the applicant had not, by his actions, sought to express the idea that a "Turkish" minority existed in Thrace. Thus, the problem was, in fact, a specific way of manifesting political views, which should have been examined under Art. 10 of the Convention, providing the right to freedom of expression. ${ }^{2}$

In light of the above, the judicial decisions of the European Court of Human Rights (and previously also the European Commission of Human Rights) have not ultimately resolved the problem of whether employees in the education sector have the right to strike. Generally, it may be concluded that based on Art. 11(1) of the Convention, the problem of the right to strike has merely been acknowledged. However, based on the Court's decisions, it is difficult to talk about any concrete guidelines which could be used to legally assess restrictions on the right to strike.

2 "The Commission does not exclude that a separate issue could arise under Article 10 (Art. 10) of the Convention, since the Council of State clearly indicated that dismissal would not have been the appropriate penalty for a few days' absence from work, if the applicant had not, by his actions, sought to express the idea that a 'Turkish' minority existed in Thrace" (Agko v. Greece). 


\section{The position of the Freedom of Association Committee of the International Labour Organisation (ILO)}

The position of the Freedom of Association Committee, ILO, regarding the right to strike in the education sector is inalterable and clear. The Committee has consistently opposed any forms of restricting this right in the education sector.

Already the joint recommendations by UNESCO and ILO concerning the status of teachers issued in 1966 indicated that "if the means and procedures established for the purpose of the settlement of disputes between the teachers and their employers should be exhausted, teachers' organizations should have the right to take such other steps as are normally open to other organizations in the defence of their legitimate interests."

ILO conventions do not directly provide for the right to strike. However, this right can be inferred from the provisions of Convention No. 87 on Freedom of Association and Protection of the Right to Organize (cf. Reda-Ciszewska 2015, p. 101). Pursuant to Art. 3(1) of this Convention, workers' and employers' organisations shall have the right to draw up their constitutions and rules, to elect their representatives in full freedom, to organise their administration and activities and to formulate their programmes. Article 3(2), on the other hand, states that the public authorities shall refrain from any interference which would restrict this right or impede the lawful exercise thereof. The only reservation provided in the Convention pertains to the armed forces and the police (Art. 9(1)).

According to the Freedom of Association Committee, ILO, restriction on the right to strike as one that is closely related to the free exercise of trade union activity, is acceptable in situations in which work interruption could pose an imminent and clear threat to the life, personal safety or health of the entire population or a part thereof (ILO 2006, p. 119, item 582; Swiątkowski 2009). For this purpose, the Committee developed a term essential services. However, it remarked that such qualification cannot be absolute as a non-essential service in certain circumstances (e.g. due to strike duration) might prove to be essential, causing the above-mentioned threats (ILO 2006, p. 119, item 582).

Nevertheless, over the years the Freedom of Association Committee, ILO, has consistently refused to recognise services provided by the public education sector as essential in the sense of the term that would allow for the prohibition of the right to strike (ILO 2006, p. 121, item 587).

In a report dated November 2008 concerning the Republic of Korea, the Committee did not agree with the arguments that "civil servants do not traditionally enjoy the

3 "Appropriate joint machinery should be set up to deal with the settlement of disputes between the teachers and their employers arising out of terms and conditions of employment. If the means and procedures established for these purposes should be exhausted or if there should be a breakdown in negotiations between the parties, teachers' organizations should have the right to take such other steps as are normally open to other organizations in the defence of their legitimate interests" (ILO/UNESCO 1966, p. 9, item 84). 
right to strike because the State as their employer has a greater obligation of protection towards them." In the case investigated by the Committee, a considerable part of the teachers had the status of public servants, according to the assurances of the Republic of Korea included in the report. In the report conclusions, the Committee emphasised that over previous years it had to deal with many cases involving restrictions on the freedom of action of teachers, indicating that workers in education are not covered by the definition of essential services or of the public service exercising the powers of public authority and should therefore have the right to strike, except for school principals and deputy principals (ILO, Report No. 351).

Furthermore, in the conclusion of a report concerning India, dated November 2007, the Committee underlined that even the possible long-term consequences of strikes in the teaching sector do not justify their prohibition (ILO, Report No. 348). This conclusion had been corroborated by other, previous reports (ILO 2006, p. 121, item 590). While on the subject, it also needs to be noted that the Committee has consistently expressed its disapproval of legal solutions restricting the right to strike with regard to academic teachers. This was marked in the conclusion of a report dated June 2011 concerning the Province of Ontario, Canada (ILO, Report No. 360).

To conclude, the Freedom of Association Committee, ILO, believes that even though there is a trend of identifying teachers as public servants who exercise the powers of public authority, in fact they do not perform tasks that would associate them with this status, the exception being principals and vice-principals (ILO 2006, p. 121, item 588). Furthermore, qualifying their tasks as ones that should be performed by workers with a special official position (Civil Servants Corps) does not automatically mean that they are essential services whose interruption could pose an imminent and clear threat to the life, personal safety or health of the entire population or a part thereof (ILO 2006, p. 119, item 582). Moreover, such qualification of their professional status does not mean that the special protection of the State which they enjoy makes their right to industrial action (including strike) redundant (ILO 2006, p. 121, item 589).

\section{Conclusion}

Under the current state of law, there are no grounds to restrict or prohibit the right to strike in the education sector. The potential subordination of teachers to the rigours binding the Civil Service Corps would require far-reaching adjustments within this institution, stemming from the constitutional provisions that would necessitate these changes. Currently, the Civil Service Corps is closely related to exercising a particular scope of public authority, which is state authority. Even if the civil service was extended to cover other forms of exercising public authority or included non-executive forms of performing the State's obligations, this would entail loosening or differentiating the rigours binding civil service members. The Freedom of Association Committee, ILO, 
on numerous occasions warned against abusive use of restrictions on teachers' right to strike, even in those countries where they enjoy the status of civil servants.

\section{References}

ILO (2006) Freedom of Association. Digest of decisions and principles of the freedom of Association Committee of the Governing Body of the ILO, $5^{\text {th }}$ Edition (revised), Geneva.

ILO, Report No. 348 (November 2007) Case No. 2364 (India), https:/www.ilo.org/dyn/ normlex/en/f?p=1000:70006:0::NO:70006:P70006_COMPLAINT_TEXT_ID,P70006_PARAGRAPH_NO:2908895,122 (access: 14 September 2020).

ILO, Report No. 351 (November 2008) Case No. 2569 (Korea, Republic of), https://www.ilo. org/dyn/normlex/en/f?p=NORMLEXPUB:70006:0::NO::P70006_COMPLAINT_TEXT_ ID,P70006_PARAGRAPH_NO:2910812,639\#C (access: 14 September 2020).

ILO, Report No. 360 (June 2011) Case No. 2803 (Canada), https://www.ilo.org/dyn/normlex/ en/f?p=NORMLEXPUB:70006:0::NO::P70006_COMPLAINT_TEXT_ID,P70006_PARAGRAPH_NO:2912451,343 (access: 14 September 2020).

ILO/UNESCO (1966) Recommendation Concerning the Status of Teachers, Paris.

Reda-Ciszewska A. (2015) Prawo do strajku w świetle konwencji o ochronie praw człowieka i podstawowych wolności, "Studia Prawno-Ekonomiczne," t. 95.

Rotkiewicz M. (2018) Komentarz do art. 78 ustawy o służbie cywilnej [in:] Ustawa o służbie cywilnej. Komentarz, Warszawa.

Stelina J. (2013) Prawo urzędnicze, Warszawa.

Świątkowski A.M. (2009) Komentarz do art. 19 ustawy o rozwiązywaniu sporów zbiorowych [in:] J. Wratny, K. Walczak (red.), Zbiorowe prawo pracy. Komentarz, Legalis.

Tomanek A. (2016) Komentarz do art. 19 ustawy o rozwiązywaniu sporów zbiorowych [in:] K.W. Baran (red.), Zbiorowe prawo pracy. Komentarz, LEX.

\section{Court sentences}

European Commission of Human Rights (1984) S. v. Federal Republic of Germany, http://hudoc. echr.coe.int/app/conversion/pdf?library=ECHR\&id=001-74617\&filename=CEDH.pdf (access: 14 September 2020).

European Court of Human Rights (1997) Agko v. Greece, 31117.96, LEX 116775.

European Court of Human Rights (2015) Association of Academics v. Iceland, 2451/16, LEX 249796.

Judgment of the Constitutional Court of 21 October 1998, K 24/98, Legalis 44983.

Judgment of the Constitutional Court of 28 October 1999, K 3/99, LEX 37318.

Judgment of the Constitutional Court of 10 April 2002, K 26/00, LEX 54052. 


\section{Legal acts}

The Constitution of the Republic of Poland of 2 April 1997, Dz.U. 1997, No. 78, item 483 as amended.

The Act of 23 May 1991 on solving collective labour disputes, Dz.U. 2019, item 174 consolidated text, as amended.

The Act of 21 November 2008 on Civil Service, Dz.U. 2018, item 1559 consolidated text, as amended. 